\title{
HYDROLYSIS OF SUCCINYLCHOLINE SALTS
}

\author{
BY \\ P. J. FRASER \\ With an AdDendum by Tudor S. G. Jones and R. H. Pain \\ From the Department of Pharmacology, Wellcome Research Laboratories, Beckenham, Kent
}

(RECEIVED JUNE 18, 1954)

Glick (1941), whilst working with various esters of choline, demonstrated that the choline salt of succinic acid was hydrolysed by horse serum and by alkali. Bovet, Bovet-Nitti, Guarino, Longo, and Marotta (1949) and de Beer, Castillo, Phillips, Fanelli, Wnuck, and Norton (1951) showed that succinyldicholine possessed powerful neuromuscular-blocking properties. The latter authors showed that eserine potentiated the paralysis of the cat gastrocnemius caused by succinyldicholine. As compound 49-164, which does not inhibit cholinesterase, produced a similar potentiation they doubted whether cholinesterase was the enzyme responsible for the destruction of succinyldicholine. This seemed worth re-investigation.

In the last two or three years many surgeons and anaesthetists have preferred succinyldicholine to other neuromuscular-blocking compounds for many surgical procedures because of its very short duration of action and its freedom from undesirable side-effects. It is ideally suited for administration as an intravenous drip to give a rapidly controllable degree of muscle relaxation. It has also found favour for use with thiopentone in electroconvulsion therapy (Arnold, Böck-Greisau, and Ginzel, 1951 ; Richards and Youngman, 1952).

Mayrhofer (1952) has, however, stated that succinyldicholine is stable in solution for several weeks outside the refrigerator and also when mixed with thiopentone. This was surprising, since succinyldicholine is unstable in alkaline solution (Glick, 1941) and the $p \mathrm{H}$ of thiopentone solution is around 11.0. It thus seemed desirable to re-examine Mayrhofer's claims. The hydrolysis of succinyldicholine at elevated temperatures, in alkaline solutions, and by pseudo-cholinesterase, has accordingly been studied. A quantitative comparison has also been made between succinyldicholine and its first hydrolysis product, succinylmonocholine, which still preserves a degree of neuromuscular-paralysing activity.

\section{Methods}

Toxicity.-Groups of 5 or 10 albino mice of either sex were used, injections being made into the tail vein.

Action on Nerve-Muscle Preparations.-The isolated rat diaphragm-phrenic nerve preparation of Bülbring (1946) was used (a) as an in vitro test for concentration of succinyldicholine, and $(b)$ for comparison of the concentrations of succinyldicholine and succinylmonocholine to give equal neuromuscular-paralysing action. The isolated organ was immersed in a Ringer-Locke solution in a $100 \mathrm{ml}$. bath, and square stimuli of $2 \mathrm{~V}$. and of $0.23 \mathrm{msec}$. duration were applied at $5 / \mathrm{min}$. to the nerve. Drugs were added from a tuberculin syringe and left in contact with the diaphragm for $3 \mathrm{~min}$. This was followed by two washes with Ringer-Locke at 3 and $6 \mathrm{~min}$. respectively, giving a total cycle of $10 \mathrm{~min}$. In $3 \mathrm{~min}$., $50 \%$ paralysis of the diaphragm twitch was produced by a concentration of about $15.0 \mu \mathrm{g} . / \mathrm{ml}$. of succinyldicholine.

Tests in vivo were performed on cats and rabbits of either sex. The cats were anaesthetized with pentobarbitone sodium (usually $40 \mathrm{mg}$./kg. i.p.), and the rabbits with urethane (amount required varied considerably). Respiration was recorded from the cannulated trachea by a tambour recorder. The bloodpressure tracing was obtained from the cannulated carotid artery and injections were made into the femoral vein (cat) or jugular vein (rabbit). The musclegastrocnemius in the cat, extensor digitorum longus in the rabbit-was stimulated via the sciatic nerve by 6 discharges/min. from a neon stimulator.

For the chick paralysis test of Buttle and Zaimis (1949) two- to three-week-old chicks of either sex were used, injections being made into the wing vein. The duration of paralysis was recorded.

Manometric Methods (Warburg , Respirometer).Single side-arm flasks were used. The substrate was placed in the side arm and the enzyme preparation and Ringer-bicarbonate, to a total volume of $3.0 \mathrm{ml}$., in the base of the flask. Reactions were allowed to proceed in an atmosphere of $95 \% \mathrm{~N}_{2}: 5 \% \mathrm{CO}_{2}$. Corrections were made for extraneous temperature and pressure variations and for spontaneous hydrolysis of the substrate. The results were recorded as $\mu \mathrm{l} . \mathrm{CO}_{2}$ evolved at $37^{\circ} \mathrm{C}$. Ringer-bicarbonate was prepared by mixing 
together, immediately before use, $50.0 \mathrm{ml}$. $0.9 \% \mathrm{NaCl}, 15.0 \mathrm{ml} .1 .26 \% \mathrm{NaHCO}_{3}$, $1.0 \mathrm{ml} .1 .2 \% \mathrm{KCl}$ and $1.0 \mathrm{ml} .1 .76 \% \mathrm{CaCl}_{2}$ (hydrated), and gassing for $10 \mathrm{~min}$. with a $95 \% \mathrm{~N}_{2}: 5 \% \mathrm{CO}_{2}$ mixture.

Cholinesterase Preparations. - Human blood was withdrawn into a dry syringe and 1 part of a saturated solution of potassium oxalate was immediately added to 10 parts of whole blood. After gently mixing, this was centrifuged and the supernatant plasma drawn off. This provided the human plasma (pseudo) cholinesterase preparation which produced about $1,500 \mu \mathrm{l}$. $/ \mathrm{CO}_{2} / \mathrm{ml}$./hr. with benzoylcholine chloride $(0.015 \mathrm{M})$ as substrate. The packed red cells were washed twice with Ringer-bicarbonate, centrifuged, and the supernatant fluids discarded. The packed, washed red cells were then haemolysed by adding distilled water up to the original blood volume. This provided the human red blood-cell (true) cholinesterase preparation which produced about $2,000 \mu \mathrm{l}$. $\mathrm{CO}_{2} / \mathrm{ml}$./hr. with acetyl- $\beta$-methylcholine chloride $(0.03 \mathrm{M})$ as substrate.

Succinylcholine Salts.-Succinyldicholine dichloride was prepared by Burroughs Wellcome and Co. Succinylmonocholine monochloride was kindly prepared for me by Dr. Tudor Jones of the Wellcome Chemical Research Laboratories (see addendum).

284C51.-This compound (Copp, 1953) is 1: 5-bis(4allyldimethylammoniumphenyl) - $n$ - pentan -3 - one dibromide,<smiles>CN(C)c1ccc(CCC(=O)CCc2ccccc2)cc1</smiles>

It has been shown by Fulton and Mogey (1954) to be a specific inhibitor of true cholinesterase with a $p I 50$ of 7.8 for true cholinesterase and a $p \mathrm{I} 50$ of less than $\mathbf{3 . 0}$ for pseudo-cholinesterase.

\section{RESULTS}

Dose-Response Curve (Rat Diaphragm).-The $\log$ dose-response curve for succinyldicholine on the rat diaphragm was substantially linear over a wide range of responses. Fig. 1 gives 6 such curves chosen at random from over 50 examples. Three of these were multipoint log dose-response curves and three were pairs of curves taken from $2 \times 2$ assays of " test " against " standard." The mean slope of these curves was 132 (i.e., 132\% change in paralysis/tenfold dose increment). Calculation from this mean slope showed that a $50 \%$ fall in concentration of succinyldicholine was accompanied by a $40 \%$ lowering of paralysis.
Effect of $\mathrm{pH}$.-Succinyldicholine solutions were buffered at $p \mathrm{H}$ 5.0, 7.4, 8.2, 8.95, and 9.5 and maintained at $21^{\circ} \mathrm{C}$. The residual succinyldicholine activities of the various solutions were compared with that of the $p \mathrm{H} 7.4$ solution on the isolated rat diaphragm-phrenic nerve preparation. The amount of control succinyldicholine chosen was such as to give $70 \%$ paralysis in $3 \mathrm{~min}$.

The difference between the \% paralysis caused by the test and by the control solutions was plotted against the time in min. after solution of the succinyldicholine in buffer (Fig. 2). Equivalent amounts of the buffers alone when added to the organ bath produced no change in the size of the muscle twitch.

These results showed no detectable hydrolysis

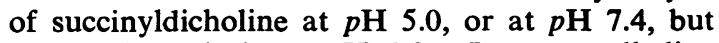
a slow hydrolysis at $p H$ 8.2. In more alkaline solutions hydrolysis was more rapid, and at $p \mathrm{H} 9.5$ there was a $50 \%$ loss of activity in just under $3 \mathrm{hr}$.

Hydrolysis in Thiopentone Solution.-Thiopentone alone on the isolated rat diaphragm caused a very marked increase in the size of the muscle twitch and in the sensitivity of the preparation to paralysis by succinyldicholine. In view of this it was necessary to remove the thiopentone from a mixture of the two drugs before a satisfactory test of succinyldicholine hydrolysis by thiopentone could be performed on the rat diaphragm. 


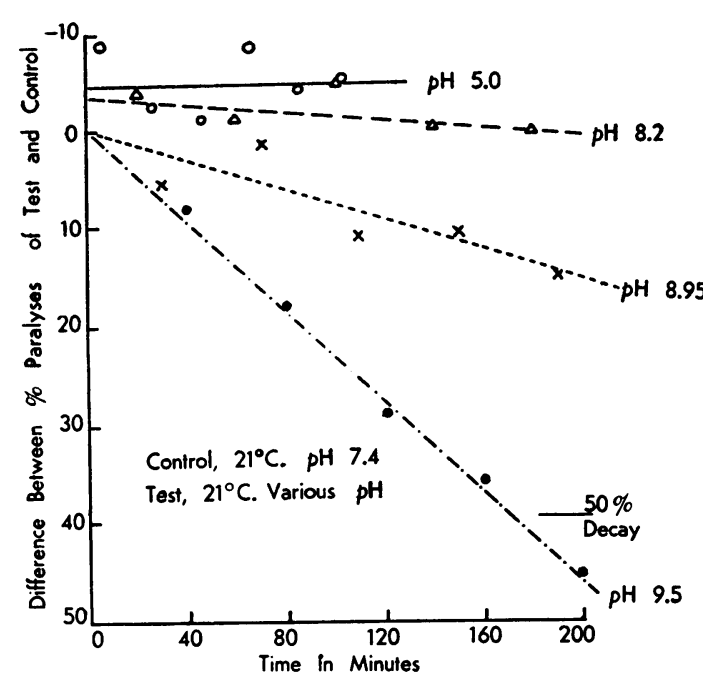

Fig. 2.-To show effect of buffered solutions at various $p H$ 's on destruction of succinyldicholine in vitro. Rat diaphragm (isolated). Ordinate: difference between \% paralysis caused by control and test samples of same initial concentrations. Abscissa: time in min. after preparation of solutions.

A solution in distilled water was prepared, each $\mathrm{ml}$. containing $3.0 \mathrm{mg}$. succinyldicholine and $10.0 \mathrm{mg}$. thiopentone. The $\mathrm{pH}$ of this mixture was 11.0 and it was maintained at room temperature $\left(20^{\circ}\right.$ C.) until aliquots were neutralized to $p \mathrm{H} 7.0$ with $\mathrm{HCl}$. This resulted in precipitation of the thiopentone which was filtered off. (A control run in the absence of succinyldicholine showed that sufficient thiopentone had been removed for such as remained to have no effect on the diaphragm.)

Half a ml. of filtrate was then added to the $100-\mathrm{ml}$. organ-bath and the paralysis occurring in 5 min. was noted. This concentration was found to give total paralysis of the diaphragm in $5 \mathrm{~min}$. when neutralization was performed immediately after preparation of the solution. No paralysis was obtained when $90 \%$ of this amount of succinyldicholine had been hydrolysed. The plot of $\%$ paralysis against $\log$ time of precipitation of the thiopentone after mixing of the two drugs, gave the straight line shown in Fig. 3. When a similar procedure was adopted using $\mathrm{NaOH}$ to pH 11.0 instead of thiopentone, total hydrolysis was obtained in under $10 \mathrm{sec}$. The significance of this will be discussed later.

Effect of Temperature.-In a series of tests similar to those for demonstrating the effert of $p \mathrm{H}$, test and control solutions were buffered at $\mathrm{pH}$ 7.4. The control solution was maintained at $21^{\circ} \mathrm{C}$. and the test solutions were incubated at temperatures of $40^{\circ} \mathrm{C}$., $50^{\circ} \mathrm{C}$., and $100^{\circ} \mathrm{C}$. respectively.

Fig. 4 presents the mean results and demonstrates the instability of succinyldicholine at tem-

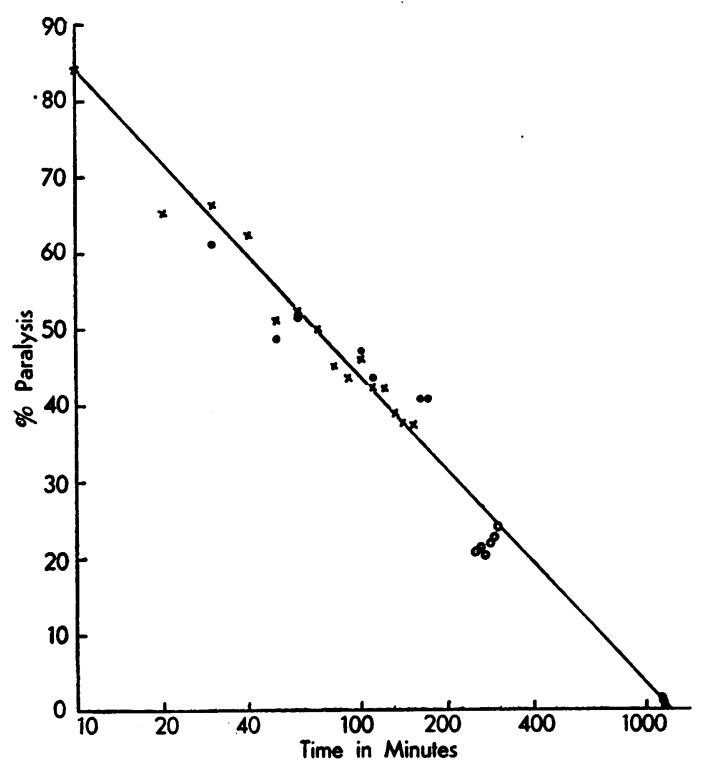

FIG. 3.-To show decay of succinyldicholine in the presence of thiopentone $(10.0 \mathrm{mg} . / \mathrm{ml}$.) pH 11.0. X, O, -three rat diaphragms. Ordinate: \% paralysis. Abscissa: log time in min. between mixing of thiopentone and succinyldicholine and precipitation of thiopentone by $\mathrm{HCl}$ to $\mathrm{pH} \mathrm{7.0.}$

peratures higher than normal body temperature, $50 \%$ hydrolysis occurring in about $30 \mathrm{~min}$. at $100^{\circ} \mathrm{C}$.

Effect of Cholinesterases.-The action of cholinesterases on the paralysing activity of succinyldicholine was also studied. For the control, succinyldicholine was buffered at $p H \quad 7.4$ and maintained at $37^{\circ}$ C. Test samples were made up in plasma, red blood cell haemolysate, whole blood, or in plasma to which eserine sulphate had been added to a final concentration of $10^{-5} \mathrm{M}$ and also incubated at $37^{\circ} \mathrm{C}$.

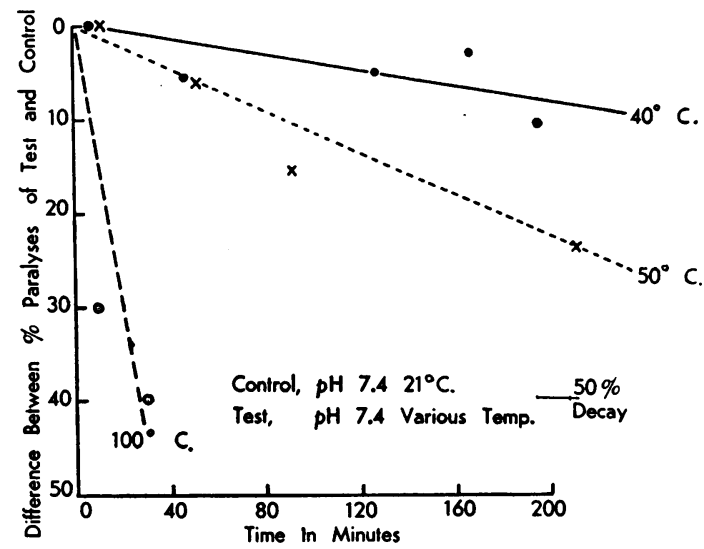

Fio. 4.-To show effect of temperature on solutions of succinyldicholine buffered at pH 7.4. Rat diaphragm (isolated). Ordinate and abscissa as in Fig. 2. 


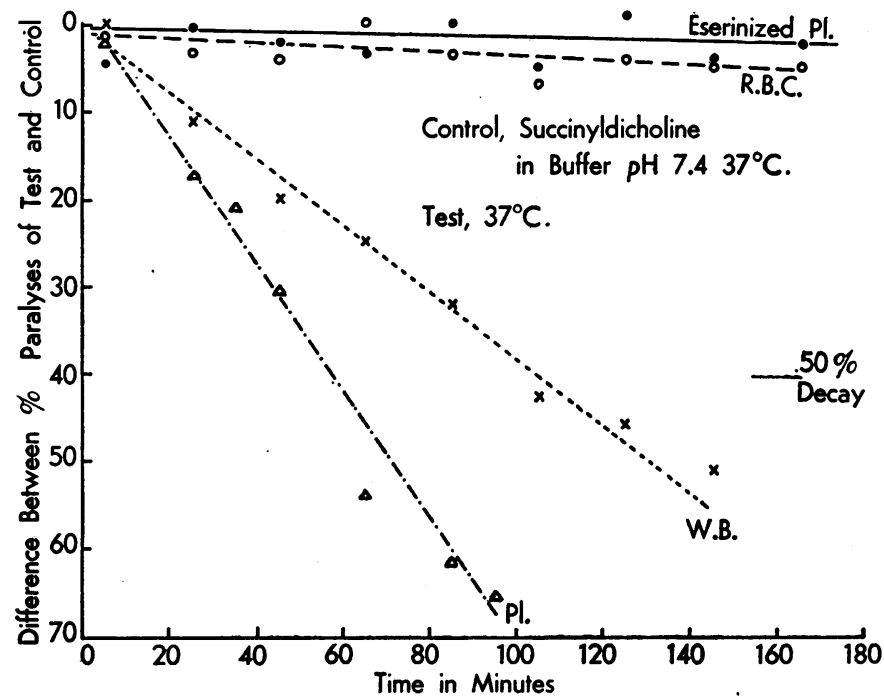

Fig. 5.-To show effect of cholinesterases on succinyldicholine in vitro. Rat diaphragm (isolated). Ordinate and abscissa as in Fig. 2. Pl, human plasma (pseudo-cholinesterase). W.B., human whole blood (true and pseudocholinesterases). R.B.C., human red blood cell haemolysate (true cholinesterase). Eserinized Pl, human plasma pseudo-cholinesterase inhibited by eserine sulphate $\left(10^{-5} \mathrm{M}\right)$.

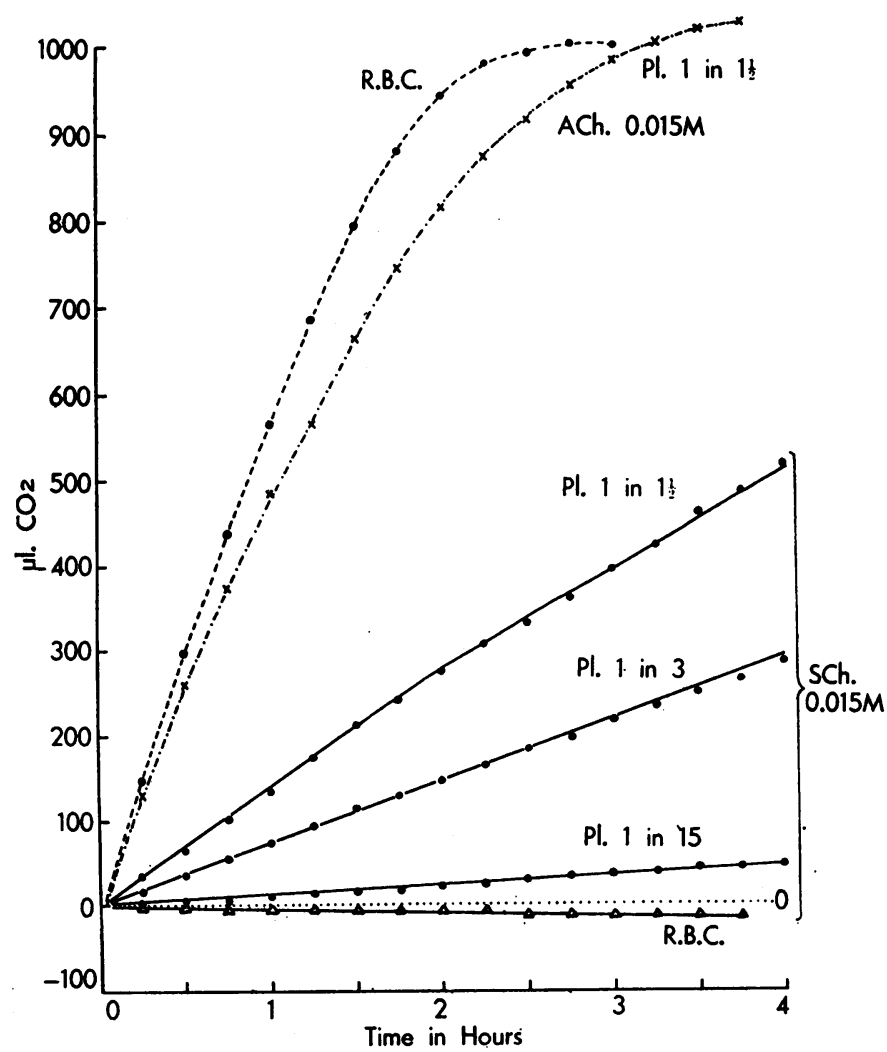

Neither red blood cells nor eserinized plasma destroyed succinyldicholine (Fig. 5). Uninhibited plasma caused rapid hydrolysis of succinyldicholine, whereas whole blood acted at a somewhat slower rate. The plasma volume in whole blood is $50-60 \%$ and, from Fig. 5, the rate of hydrolysis in whole blood was $60 \%$ of that in plasma. These results show that, in vitro, succinyldicholine was hydrolysed by pseudo-cholinesterase but was unaffected by either true or inhibited pseudo-cholinesterase.

This was also demonstrated in the Warburg respirometer using three concentrations of human plasma, human red blood cell haemolysate, and eserinized plasma. In Fig. 6 the hydrolysis curves for acetylcholine chloride have been included for comparison.

Cat Gastrocnemius.-Rapid destruction of succinyldicholine in vivo was shown by the short duration of paralysis of the cat gastrocnemius muscle on intravenous injection of the drug. Further, identical injections repeated at 15-min. intervals caused the same degree $(\%)$ and duration of paralysis after the first few injections; hence there was no evidence of accumulation of succinyldicholine in the animal.

In the experiment shown in Fig. 7, the cat was given a series of injections of succinyldicholine $(0.04 \mathrm{mg} . / \mathrm{kg}$. $)$ until a constant response was obtained. At the arrow B, $0.2 \mathrm{mg}$. $/ \mathrm{kg}$. 284C51 was given intravenously. This was sufficient to cause a considerable depression of true cholinesterase activity in the blood stream but to have no effect on the pseudo-cholinesterase. Following this by the standard injection of succinyldicholine there was no change from the response obtained before 284C51. After $0.2 \mathrm{mg} . / \mathrm{kg}$.

FIG. 6.-To show hydrolysis of succinyldicholine by cholinesterases in vitro. Warburg respirometer. Upper two curves show hydrolysis of acetylcholine $(0.015 \mathrm{M})$ by human plasma and red blood choline $(0.015 \mathrm{M})$ by human plasma and red blood
cells. Lower four curves show hydrolysis of cells. Lower four curves show hydrolysis of of human plasma, and lack of hydrolysis by human red blood cells. Ordinate: corrected output of $\mathrm{CO}_{3}$ in $\mu \mathrm{l}$. Abscissa: time in hr. 
eserine sulphate, which gave $40 \%$ inhibition of the pseudo-cholinesterase, the paralysis caused by the standard dose of succinyldicholine was increased and prolonged. Normal cat plasma had half the pseudo-cholinesterase activity of human plasma. Fig. 8 presents the results of a typical experiment, and shows how the maximum effect of the eserine in potentiating the succinyldicholine was not achieved until about $1 \mathrm{hr}$. after the eserine was injected intravenously, despite the fact that this dose of eserine caused its maximum inhibition of the plasma pseudo-cholinesterase within $10 \mathrm{~min}$. of the injection.

Chick Paralysis.-Intravenous injection of succinyldicholine into the chick causes a spastic paralysis of the leg and neck muscles (Buttle and Zaimis, 1949). Using a dose of $0.03 \mathrm{mg} . / \mathrm{kg}$., a spastic paralysis lasting 3-4 min. was obtained. $0.5 \mathrm{mg}$./ kg. 284C51 given half an hour before the succinyldicholine produced no change in the duration of paralysis from that found in the controls. Similarly, eserine sulphate at $0.1 \mathrm{mg}$. $/ \mathrm{kg}$. and 0.2 $\mathrm{mg} / \mathrm{kg}$. caused no significant prolongation of paralysis; but when $0.5 \mathrm{mg}$. $/ \mathrm{kg}$. was given half an hour before the succinyldicholine the duration

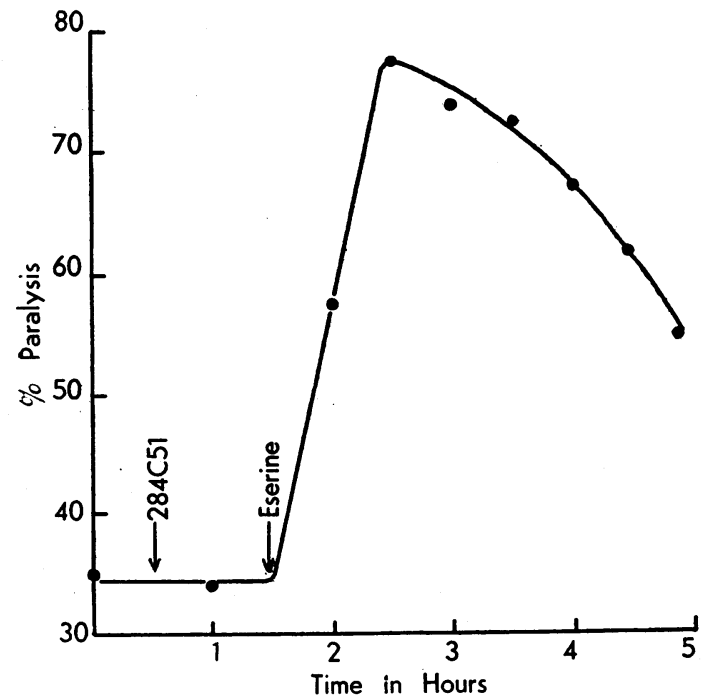

FIG. 8.-Graphical presentation of potentiation of succinyldicholine paralysis of cat gastrocnemius by eserine. Ordinate: \% paralysis of gastrocnemius muscle. Abscissa: time in hr. At first arrow: 284C51 0.2 mg.kg. i.v.; at second arrow: eserine sulphate $0.2 \mathrm{mg} . / \mathrm{kg}$. i.v. $\mathrm{mg}$. Each dot represents \% paralysis of the muscle caused by $0.04 \mathrm{mg} . / \mathrm{kg}$. succinyldicholine i.v. of paralysis was extended to 7-8 min.-an increase of $80-100 \%$. Normal chick plasma had 1/18 of the pseudo-cholinesterase activity of human plasma with benzoylcholine as substrate, and was also capable of hydrolysing succinyldicholine at a slow rate, as is shown in Fig. 9.

Recovery in Rabbits.-Bourne, Collier, and Somers (1952) and Evans, Gray, Lehmann, and Silk (1952) have demonstrated a low pseudocholinesterase level in the plasma of patients who

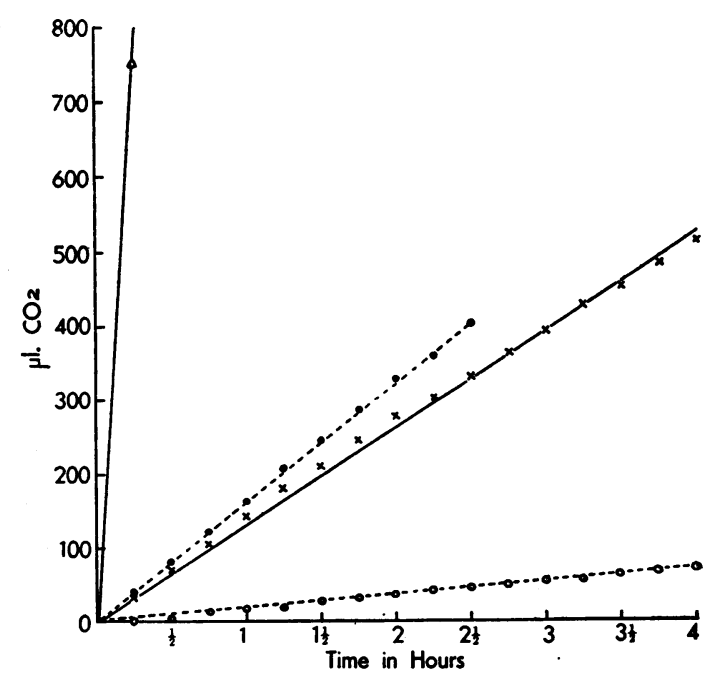

FIG. 9.-To show hydrolysis of succinyldicholine by chicken plasma. Warburg respirometer. Ordinate: $\mu \mathrm{l}$. $\mathrm{CO}_{2}$. Abscissa: time in $\mathrm{hr} . \Delta-\Delta$ Human plasma $\left(1\right.$ in $\left.1 \frac{1}{2}\right)+$ benzoylcholine (0.015M). $X-X$ Human plasma (1 in $\left.1 \frac{1}{2}\right)+$ succinyldicholine (0.015M). $(0.015 \mathrm{M})$. O- - 0 Chicken plasma ( 1 in $\left.1 \frac{1}{2}\right)+$ succinyldicholine $(0.015 \mathrm{M})$. 
had unusually prolonged recovery times from succinyldicholine apnoea. In view of the findings of Koelle (1953), that rabbits fall into two distinct groups on the basis of their plasma pseudocholinesterase levels, rabbits were used to determine whether the low-activity group would take longer to recover from succinyldicholine paralysis than the high-activity group. Some 20 rabbits from each group were used and the extensor digitorum longus muscle was stimuated via the sciatic nerve. It was not possible to demonstrate any relationship between plasma pseudo-cholinesterase level, sensitivity to succinyldicholine, and time for recovery of the muscle from $66 \%$ paralysis to $33 \%$. Enzyme estimations performed on this muscle failed to show any appreciable pseudo-cholinesterase activity.

Succinylmonocholine Monochloride.-This compound, which is the first hydrolysis product of

TABLE I

COMPARISON OF ACTIVITIES OF SUCCINYLDICHOLINE AND SUCCINYLMONOCHOLINE

\begin{tabular}{|c|c|c|c|c|}
\hline \multirow{2}{*}{$\begin{array}{c}\text { Test } \\
\text { Animal }\end{array}$} & \multirow{2}{*}{$\begin{array}{l}\text { Criterion for } \\
\text { Comparison }\end{array}$} & \multicolumn{2}{|c|}{ Dose of Drug } & \multirow{2}{*}{$\begin{array}{l}\text { Ratio of } \\
\text { Activity of } \\
\text { Succinyl- } \\
\text { dicholine } \\
\text { to Succinyl- } \\
\text { monocholine }\end{array}$} \\
\hline & & $\begin{array}{l}\text { Succinyl- } \\
\text { dicholine }\end{array}$ & $\begin{array}{c}\text { Succinyl- } \\
\text { monocholine }\end{array}$ & \\
\hline \multirow[t]{3}{*}{$\begin{array}{l}\text { Mouse } \\
\text { Rat }\end{array}$} & $\begin{array}{l}\text { i.v. LD50 (mg./kg.) } \\
50 \% \text { paralysis dia- }\end{array}$ & 0.455 & 4.66 & $10: 1$ \\
\hline & $50 \%$ paralysis of & 0.9 & $10 \cdot 0$ & $11: 1$ \\
\hline & $\begin{array}{l}\text { muscle (mg. } / \mathrm{kg} \text {.) } \\
\text { 3-4 mins. duration }\end{array}$ & 0.025 & 1.0 & 40: 1 \\
\hline Chick & (mg./kg.) & 0.03 & $15 \cdot 0$ & 500: 1 \\
\hline
\end{tabular}

succinyldicholine, had similar qualitative actions. Quantitatively, however, it differed, the ratio of activities varying according to the test animal (Table I).

In the Warburg respirometer, succinylmonocholine was hydrolysed by human plasma pseudocholinesterase (see Fig. 10). The ratio of the rate of hydrolysis of succinyldicholine to that of succinylmonocholine was 1.4. No hydrolysis was obtained with human red blood cells or with eserinized plasma (eserine $10^{-5} \mathrm{M}$ ).

\section{Discussion}

Using the isolated rat diaphragm, it has been shown that succinyldicholine is unstable in alkaline solutions and at temperatures above about $40^{\circ}$ C. Increasing alkalinity or increasing temperature led to a faster rate of destruction of the succinyldicholine. In Figs. 2 and 4, summarizing these results, a straight line was obtained by plotting \% paralysis of the rat diaphragm against incubation time. Fig. 1 showed that, on the rat diaphragm, \% paralysis was directly proportional to $\log$ concentration, and hence the hydrolysis of succinyldicholine both by alkali and by heat, was a first-order reaction. The same deduction also applied to the hydrolysis by pseudo-cholinesterase (Fig. 5). The reaction with thiopentone was different. Firstly, the rate of destruction of succinyldicholine by thiopentone at $p \mathrm{H} 11.0$ was very much less rapid than that obtained with $\mathrm{NaOH}$ at $p \mathrm{H} 11.0$; secondly (Fig. 3), a straight line was only obtained when $\%$ paralysis was plotted against $\log$ time-thus this was a second-order

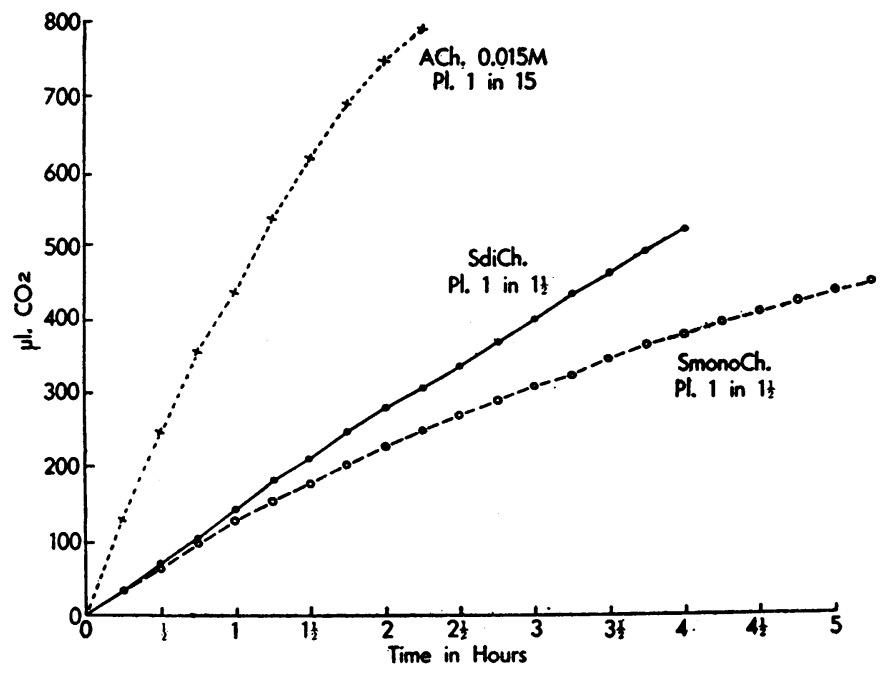

FIO. 10.-To show hydrolysis of succinylmonocholine by pseudo-cholinesterase in vitro. Warburg respirometer. Ordinate: $\mu \mathrm{l} . \mathrm{CO}_{\mathbf{2}}$. Abscissa : time in hr. X-- $-X$ Human plasma ( 1 in 15) +acetylcholine $(0.015 \mathrm{M})$. - Human plasma $\left(1\right.$ in $\left.1 \frac{1}{2}\right)+$ succinyldicholine $(0.015 \mathrm{M})$. O-- - O Human plasma $\left(1\right.$ in $\left.1 \frac{1}{2}\right)+$ succinylmonocholine (0.015M). 
reaction. The result was suggestive of a reaction occurring between the succinyldicholine and the thiopentone as well as the straightforward alkaline hydrolysis. The rate of $50 \%$ loss of activity in the first $90 \mathrm{~min}$. was sufficiently fast to make it inadvisable to mix thiopentone and succinyldicholine in the one syringe for intravenous injection.

The in vitro enzyme experiments agreed with those of previous authors (Glick, 1941; de Beer et al., 1951 ; Whittaker, 1951 ; Evans et al., 1952) that succinyldicholine salts were destroyed by pseudo-cholinesterase, but differed from those of Bovet-Nitti (1949) and Tamme in (1953), who demonstrated hydrolysis by both cholinesterases. In vivo experiments in the cat and chick also showed that destruction of the true cholinesterase had no effect on the sensitivity to succinyldicholine, whereas inhibition of pseudo-cholinesterase considerably potentiated the paralysis caused by a standard injection of the drug. Further, in the cat, maximum inhibition of pseudo-cholinesterase in the plasma occurred in under $10 \mathrm{~min}$. after intravenous injection of $0.2 \mathrm{mg}$. $/ \mathrm{kg}$. eserine sulphate. However, maximum potentiation of succinyldicholine did not occur until $1 \mathrm{hr}$. after the injection of eserine (Fig. 8). It thus appeared that the pseudo-cholinesterase level in the plasma was not the only factor determining the duration of action of succinyldicholine in vivo (cf. de Beer et al., 1951). Further support was provided by the rabbit experiments, where it was not possible to demonstrate any relationship between plasma pseudo-cholinesterase level, sensitivity to succinyldicholine and time for recovery of the extensor digitorum longus muscle from $66 \%$ paralysis to $33 \%$. Enzyme estimations performed on this muscle showed only slight pseudo-cholinesterase activity. It is suggested that, although the plasma enzyme level plays an important part in determining the effect of an injection of succinyldicholine, other factors-for example, the pseudo-cholinesterase concentration in the muscle-may be equally important.

Succinylmonocholine was similar in its actions to succinyldicholine but much less active (Table I). The ratio of $40: 1$ on the cat gastrocnemius was confirmed by Collier and Macauley (1953) on the cat tibialis. In the hydrolysis by human plasma pseudo-cholinesterase (Fig. 10) there was a slight discrepancy between these results and those reported by Lehmann and Silk (1953). Calculation from Lehmann and Silk's figures gave a ratio of the rate of hydrolysis of succinyldicholine to that of succinylmonocholine, of 1.67 at $0.055 \mathrm{M}$ concentration of substrates, and of 3.8 at $0.0055 \mathrm{M}$, as compared with 1.4 at substrate concentrations of $0.015 \mathrm{M}$ in the experiments reported here. The concentration of enzyme used was, however, approximately three times greater in Lehmann and Silk's experiments and this probably accounts for the difference in the ratios.

\section{SUMMARY}

1. Succinyldicholine is unstable in alkaline solutions, the rate of destruction increasing with increasing alkalinity. The reaction is of the first order, and at $p \mathrm{H} 9.5$ there is $50 \%$ loss of activity in just under $3 \mathrm{hr}$.

2. Mixed with thiopentone, succinyldicholine is rapidly hydrolysed, with $50 \%$ loss of activity in $90 \mathrm{~min}$. There is apparently a reaction between the succinyldicholine and the thiopentone, since the decay curve shows it to be a second-order reaction.

3. Succinyldicholine is unstable in solution at temperatures above $40^{\circ} \mathrm{C}$. At $100^{\circ} \mathrm{C}$. there is $50 \%$ loss of activity in $30 \mathrm{~min}$. The reaction is of the first order.

4. In vitro, succinyldicholine is hydrolysed by pseudo-cholinesterase but not by true cholinesterase or eserine-inhibited pseudo-cholinesterase.

5. In vivo, destruction of true cholinesterase by injection of 284C51 (a specific inhibitor of true cholinesterase) does not alter the response to succinyldicholine, whereas inhibition of the pseudocholinesterase by eserine considerably sensitizes the animal to succinyldicholine. Since maximum sensitization of a muscle is not achieved until $1 \mathrm{hr}$. after the eserine has been given intravenously, and since in rabbits there was no correlation between plasma pseudo-cholinesterase level and sensitivity of a muscle to succinyldicholine, it is suggested that factors other than plasma pseudo-cholinesterase concentration assist in determining the final effect of succinyldicholine on the muscle.

6. Succinylmonocholine has been compared with succinyldicholine and found to be qualitatively similar in its actions but considerably less potent.

I wish to acknowledge the help and advice given by Dr. A. C. White, and the competent technical assistance of Miss L. S. Brooks and Messrs. F. Huggins and D. J. Tulett.

This paper was in part communicated to the meeting of the British Pharmacological Society on January 3, 1953. 


\section{A D D E N D U M}

\section{PREPARATION OF SUCCINYLMONO- CHOLINE ESTER SALTS}

\author{
By Tudor S. G. Jones and R. H. Pain
}

The preparation of succinylmonocholine ester salts has been recently described by Phillips (1953), but before this a method was tried independently in order to provide material for the above and other work. Phillips found two methods to give satisfactory yields of salts of the ester: (1) esterification of 2-dimethylaminoethanol with acetic anhydride, followed by quaternation with methyl iodide, (2) direct esterification of choline iodide with acetic anhydride, in a melt at $140^{\circ}$ C. A third attempt by partial hydrolysis of the di-ester iodide with alkali gave only some unchanged diester, succinic acid and sodium iodide. Our experiments, including examination of the products by paper chromatography, are in complete agreement with this last finding. The method of preparation adopted by us involved the discovery of a solvent-nitromethane-which dissolved both choline chloride and succinic anhydride.

Preparation of Succinylmonocholine Ester Chloride.Choline chloride (7 g.) dried over $\mathrm{KOH}$ in vacuo and succinic anhydride (10 g., 2 equiv.) were dissolved in nitromethane $(250 \mathrm{ml}$.) and refluxed for $3 \mathrm{hr}$. The solvent was removed by distillation. The residue was extracted under reflux successively with $350 \mathrm{ml}$. and $200 \mathrm{ml}$. of anhydrous ethyl ether and finally washed with dry ether. The product was dissolved in a minimum of hot ethanol and ether added to incipient crystallization. On cooling, a fine crystalline precipitate $(10.7$ g.) was obtained, filtered off and washed with dry ether. On recrystallization the yield was 9.9 g., m.p. $150-151^{\circ}$. It is readily recrystallized from ethanol. (Found: C, $45.1 ; \mathrm{H}, 7.2 ; \mathrm{N}, 5.9 ; \mathrm{Cl}, 14.80 . \mathrm{C}_{0} \mathrm{H}_{18} \mathrm{NO}_{4} \mathrm{Cl}$ requires C, $45.1 ; \mathrm{H}, 7.5 ; \mathrm{N}, 5.9 ; \mathrm{Cl}, 14.80 \%$.)
Preparation of Succinylmonocholine Ester Perchlorate. -The chloride $(1.7$ g.) was dissolved in water and an equivalent volume of silver perchlorate solution added. After boiling to coagulate the $\mathrm{AgCl}$, which was removed by filtration, the solvent was evaporated under reduced pressure and the residual oil dried azeotropically with ethanol and benzene. Crystalline material was obtained from strong ethanol solution by seeding a strongly cooled solution, m.p. 116-117 ${ }^{\circ}$. (Found: C, 35.6; $\mathrm{H}, 5.8 ; \mathrm{N}, 4.8 . \quad \mathrm{C}_{9} \mathrm{H}_{18} \mathrm{NO}_{8} \mathrm{Cl}$ requires $\mathrm{C}, 35.6 ; \mathrm{H}, 6.0$; $\mathrm{N}, 4.6 \%$.)

\section{REFERENCES}

Arnold, O. H., Böck-Greisau, W., and Ginzel, K. H. (1951). Wien. med. Wschr., 101, 492.

de Beer, A. J., Castillo, J. C., Phillips, A. P., Fanelli, R. V., Wnuck, A. L., and Norton, S. (1951). Ann. N.Y. Acad. Sci., 54, 362.

Bourne, J. G., Collier, H. O. J., and Somers, G. F. (1952). Lancet, 1, 1225.

Bovet, D., Bovet-Nitti, F., Guarino, S., Longo, V. G. and Marotta, M. (1949). R.C. Ist. sup. Sanitd, 12, 111.

Bovet-Nitti, F. (1949). Ibid., 12, 357.

Bülbring, E. (1946). Brit. J. Pharmacol., 1, 48.

Buttle, G. A. H., and Zaimis, E. J. (1949). J. Pharm. Pharmacol., 1, 991.

Collier, H. O. J., and Macauley, B. M. (1953). Brit. med. J., 1, 1279.

Copp, F. C. (1953). J. chem. Soc., 3116.

Evans, F. T., Gray, P. W. S., Lehmann, H., and Silk, E. (1952). Lancet, 1, 1229.

Fulton, M., and Mogey, G. A. (1954). Brit. J. Pharmacol., 9, 138.

Glick, D. (1941). J. biol. Chem., 137, 357.

Koelle, G. B. (1953). Biochem. J., 53, 217.

Lehmann, H., and Silk, E. (1953). Brit. med. J., 1, 767. Mayrhofer, O.'K. (1952). Ibid., 1, 1332.

Phillips, A. P. (1953). J. Amer. chem. Soc., 75, 4725.

Richards, H., and Youngman, H. R. (1952). Brit. med. J., $1,1334$.

Tammelin, L.-E. (1953). Acta chem. scand., 7, 185.

Whittaker, V. P. (1951). Experientia, 7, 217. 